\title{
The Narrative about the History of the Shenekhen Buryats
}

\author{
L. B. Badmaeva ${ }^{1}$ \\ ${ }^{1}$ Ulan-Ude, Institute for Mongolian, Buddhist and Tibetan Studies SB RAS, Russian Federation \\ Correspondence: L. B. Badmaeva, Ulan-Ude, Institute for Mongolian, Buddhist and Tibetan Studies SB RAS, \\ Russian Federation
}

Received: November 25, 2019; Accepted: April 13, 2020; Published: April 24, 2020

\begin{abstract}
The article is devoted to the narrative written by Bodongut Abida about the history of the emigration of the Aga Buryats to China at the beginning of the XX century, which was of an economic and ethno-protective nature. The aim of this research is to introduce into scientific circulation a new document on the history of Buryat emigration. In the Soviet historiography until now days, it was customary to keep silent about the emigration of the Buryats to China. The main attention is focused on the content of the written monument in the Old Mongolian script. The structure of the work is considered. For the first time is given the biographical information about Bodongut Abida. The data used for this research were taken from this document and the Buryat chronicles written in Old Mongolian script in XIX century. Based on the results of the analysis, it was found that the process of loss of the native language and the ethnic identity among the Buryats of China received significantly less development than the Buryat ethnos in Russia. The empirical material shows that the one of the most important factors in the consolidation of the ethnic group and the ethnic identity of the Shenekhen Buryats is the language, the possession of the Mongolian script, which is the traditional letter of the Mongolian peoples. Besides the sense of national pride and national self-awareness, as well as the factor of the compact settlement of the ethnos in the dominant Mongolian-speaking environment are the factors of their consolidation. In addition, the present state of the language and culture of the Shenekhen Buryats is presented, based on the expedition materials of the author of this paper.
\end{abstract}

Keywords: historical narrative, written monument, history of the emigration of the Aga Buryats, Shenekhen Buryats of China, historical source, Old Mongolian script, Buryat chronicles

\section{Introduction}

As we know, the migration processes are common phenomenon at all stages of the human history. Their scales and directions of movements are determined by the specific political, economic, sociocultural conditions. Until recently in national historiography, it was customary to remain silent on the fact of the emigration of the Buryats to China at the beginning of the $20^{\text {th }}$ century, because all themes related to the Buryat emigration fell into the category of "banned". The history of the Aga Buryats' emigration to China to the Shenekhen area was described in detail in the Bodongut Abida's (1917-2006) work "Buriyad mongyol-un tobči teüke" ("The brief history of the Buryat-Mongols") [BA], published by the Department of Culture of the Inner Mongolia PRC (Öbür mongyol-un soyul-un keblel-ün qoriy-a) in 1983 in the Old Mongolian script.

According to his own information, Bodongut Abida was born on February 2, 1917 in the Aduun-Chuluun area of the Borzya somon (modern Zabaykalsky Krai). Yabagan bagsha Tsyrendorzhyn Yunden taught him the Old Mongolian script. In 1928 Bodongut Abida with his parents went to Shenekhen. In Shenekhen he was grazing the cattle of the rich tatar Sokolov, who taught him the Russian language. When the Japanese occupied Khulun-Buir, he was appointed a scribe of the khoshun Solon (holoon khushuun). At that time, the paperwork was conducted in the Manchu language, so he hastily had to learn the Manchu language within six months. Then he studied in Chan'Chun at the Railway Institute ("Tümer qarguin deede hurguuli"), which was opened by the Japanese. At the institute, he learned the Japanese language. After graduating in 1938, he worked in Hailar as a cashier at the railway station. Later he was appointed a teacher of the Mongolian language in the Japanese railway secondary school ("Tumer qarguin dunda hurguuli"). In 1947-1952 years B. Abida worked as the head of the Shenekhen Western Somon (Shenekheen Baruun homonoi darga).

In 1952-1961 years, he was the head of the Department of Agriculture of the Solon khoshun (holoon). Since 1961, he held managerial positions in the government structures of the Khulun-Buir Aimak, such as the Committee for Nationalities Affairs. In 1988 Bodongut Abida retired. 
It is known that besides of the following works "Buriyad mongyol-un tobči teüke" ("The brief history of the BuryatMongols"), "Sineken-ü buriyadčud-un oyir-a-yin teüke-yin toyimu" (Review of the modern history of the Shenekhen Buryats), B. Abida wrote a great book in Chinese about the history of the war on Khalkhin-gol. Then this work was translated into Mongolian and published in Mongolia in 2005 (Nomun khanai dain. - Ulaanbaatar, 2005. - 278 p.).

In our memory, Bodongut Abida-guai remained as a man of amazing erudition, great hard worker who lived a long and difficult life, in which the fate of a small Buryat diaspora is reflected. By fate this small Buryat's diaspora found themselves in a foreign land, and not lost themselves, but preserved in the best possible way the language and culture of the mother ethnic.

Here is the pedigree of B. Abida, written down from his words (by sons' line Sonin, Solmon): Bargu - Khoridai Bodonguud - Urgudai - Khuvandai - Khundai - Malzhuu - Gusuren - Khee Bara - Chindamuni - Tsedeb Khagdaa - Tubshin - Shara Tolgoi - Shabar - Buzhaa - Buural - Tegulter - Ondori (Andrey) - Ekhe Ochir - Ekhe Badma - Budazhab - Tserenzhab - Abida - (daughters) Subad, Medegma, Tuyaa, 1. (the first son) Sodo - Sonin; 2. (the second son) Solmon - (daughters) Sodon-guvaa, Sonor-guvaa, Soyolmaa (Note 1).

The editor of the publication, Huasai Dugarzhab writes in his introduction: "Although Bodongut Abida does not specifically deal with the history of the Mongolian peoples, nevertheless, his perfect knowledge of Mongolian, Chinese, Russian and Japanese languages; scrupulous collection of the documentary materials for a long time and careful analysis of the factual material allowed him to write an interesting work on the history of Mongolianspeaking peoples, in particular on the history of the Buryat-Mongols. It is thought that this work will be especially useful for researchers of the history of the Mongolian peoples" (Bodongyud, 1983 p. 3).

The work has a harmonious and logical composition. The text is delimited into 19 entitled paragraphs: preface, 1) the formation of the Buryat ethnic; 2) Buryat-Mongols of the Chinggis Khan era; 3) Buryat-Mongols of the era of the collapse of the Mongolian empire; 4) the beginning of the Russian colonization of the Buryat-Mongolian lands; 5) the spread of the Buddhist religion among the Buryat-Mongols; 6) changes in life of the Buryat-Mongols; 7) the administrative structure of the Buryats; 8) the traditional economies of the Buryats and its development; 9) culture and education of the Buryat-Mongols; 10) the revolutionary movement in Buryat-Mongolia; 11) the origin of the Shenekhen Buryats; 12) the formation of the Buryat administrative management in Khulun-Buir; 13) about the Buryats' exodus to Shilin-gol leaded by Rinchindorzhi; 14) the condition of the Buryats after their resettlement in Khulun Buir; 15) the condition of the Buryat-Mongols during the Japanese aggressive colonization; 16) the condition of the Buryats during the Second World War; 17) destruction during the Japanese colonization; 18) the anti-revolutionary movement of Rinchindorzhi; 19) the life of the Buryat-Mongols in Khulun-Buir under the leadership of the party; conclusion.

According to Bodongut Abida, the Buryats' exodus to Shenekhen (PRC) was connected with the historical events that took place in Russia in the early twentieth century such as the beginning of the First World War, the mobilization of the Buryat youth for the rear works, the revolutionary unrest within the country and so on. The representatives of the Buryat sites, noyons and the Buddhist spiritual hierarchy were especially concerned about the strengthening of the revolutionary movement in Russia. They organized a delegation headed by Namdag-noyon (the grandson of the Aga taisha - the head of the Aginsk steppe Duma Tugultur Toboyev - L.B.) and M.N. Bogdanov, a well-known Buryat public figure, to Hailar to the administration of the aimak. The Chinese officials reacted quite ambiguously to the request of the Buryats about the permission to move to Khulun-Buir. Some of them expressed categorical opposition to the migration of the Buryats to the territorial lands of Khulun-Buir. But some officials, in particular Gun Tsendu and his like-minded people, in every way contributed to the realization of the plans of the Buryat leaders; because they were interested in developing and settling the desert lands that stretched along the northern foothill of Khingan. These lands were free because of the anthrax epidemic and because of the gangs of robbers, which settled there. (Subsequently, the Buryats burned down the soil to eliminate the foci of epizootics).

On information of Ayusha Zhamsarano, who participated in the negotiations with Chinese sites, as a result of repeated meetings and negotiations, the Buryats were allowed to settle on the lands on the southern part of the Argun River, from the Khabul River to the southwest of the Telburkhen River up to the upper flow of the Hailar River. Then from the rivers Mogoi, Tenikhe to the west up to the Shenekhen River, from there to the southwest up to the Khandagai River and up to the northern foot of the Khingan Range. The basin of the rivers Shenekhen, Uydkhen, Ono and the lower flow of the river Khuyn-gol was defined as a center of the settlement of the new settlers (Bodongyud, 1983, p63). At the same time, among the Buryats themselves, many of them disapproved of 
the issue of emigration to the Inner Mongolia. Some lamas opposed the relocation of the Buryats and claimed:

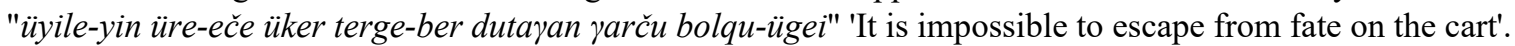

Nevertheless, at the beginning of 1918, some part of the Aga Buryats and part of the Khamnigans, led by Namdagnoyon, took their workers, livestock and property and migrated to Khulun Buir, to the Shene Barga area of the Right khoshun and to the Starobargut khoshun. Then in 1922, the first 160 families immigrated to the Shenekhen area, in total 700 people. Thus, they formed the Buryat khoshun. Radnyn Abida was appointed a khoshun darga and Zhamsarano Ayushi - his deputy. The structure of the administrative system in Khulun-Buir was organized like military devisions of the army of the Tsyn Empire. Khoshun consisted of four somons. Each somon was led by zangi, khafan, four bošuqu 'boshkho'. In addition, one military somon (meyen čerig 'sentry') was created to guard and protect the Khoshun. Armament was ensured the administration of the aimak, and khoshun was temporarily duty to provide with the following accoutrements such as carts, saddle horses, accommodation, rations. The commander of the military unit was baptized buryat Gombozhab, who was trained in the military skills. He conducted exercises to train cavalrymen.

As Bodongut Abida writes, the Buryats since 1922 continued to arrive in Khulun-Buir. As a result, in 1929 it was decided to divide the Buryat Khoshun into two Khoshuns (right and left). In the spring of 1929, the construction of the Buddhist monastery šineken süm-e 'Shenekhen Monastery' was completed.

While writing the work the author used materials from "The Secret History of the Mongols", from the work of the Japanese scientist Kobayashi Takashiro "Činggis qayan-u čedeg" ("The Life of Chinggis Khan"), from the Buryat chronicles Tugultur Toboyev, Vandan Yumsunov, Shirab-Nimbu Khobituev, as well as materials from "The History of the Mongolian State", "The History of the Buryat-Mongolian ASSR", from the works of B.Ya. Vladimirtsov, in addition, from oral memories of the elders of the Shenekhen Buryats: Dashanima, Danzan, Munkhe, Denzen, Dulbe, Balig-Bator and other.

In addition to this mentioned work one more book about the history of the Shenekhen Buryats: "Sineken- $-\ddot{u}$ buriyadčud-un oyir-a-yin teüke-yin toyimu" 'The overview of the modern history of the Shenekhen Buryats' by B. Abida, B. Dimchig, Z. Bulad, S. Lkhamasuren was published in 1985 in the publishing house of the Department of culture of the Inner Mongolia PRC.

These works, which were published with the participation of Bodongut Abida, are the single sources of the history of the Shenekhen Buryats.

At present, the Shenekhen Buryats live in two somons (Baruun homon 'Right or Western Somon', Zuun homon 'Left or Eastern Somon') of the Evenk Khoshun of the Autonomous Region of the Inner Mongolia PRC. Their population is 7632 people: 3012 people live in Zuun Somon (Eastern Somon), in Baruun Somon (Western Somon) - 2240 people, in other places - 2380 people (Note 2). Mainly they are posterity of the Aga Buryats from three somons of the Tsugol khoshun (Borzhya-Shenestuy, Beligtuy and Khuandin) which immigrated to the territory of the Inner Mongolia in 1920. According to the archival materials, 373 families moved from the Borzhya-Shenestuy Somon, including 925 men, 246 women; from Beligtuy - 126 families, including 261 men, 246 women; from Khuandin Somon - 381 family, including 1483 men, 1452 women.

A small percentage of the Buryat emigrants in Shenekhen are from Barguzin, Khori, Bichura, Selenginsk and Dzhida aymaks of Buryatia. According to the information of the Shenekhen Buryats, the descendants not only of the Zabaykalsk Buryats live in Khulun-Buir, but also the descendants of the Irkutsk region: the descendants of the Bokhansk and Balagan Buryats, in particular Khazagaevs, Shapkhaevs, Pirozhkovs (the descendants of Apolon Khazagayev and Socrat Pirozhkov, from the clan of Idina Taisha, in past owners of the mill of Ivan and Ilya Pirozhkovs). However, their descendants have already assimilated with the Chinese, since they live separately in cities.

The fact that the Buryats, when they emigrated to China, not casually chose a place for the settlement in KhulunBuir, where the Barguts, the Dagurs, the Evenks, the Olets live, speaks that the historical memory of the people has preserved the information about the ancient ties of the Buryats with the Barguts and the Dagurs. For example, chronicle monuments of Buryatia, created in the XIX century, write that the representatives of the Khori Buryats live among the Barguts of China, in particular among the Shene-barguts. In particular, the Buryat author Shirab-

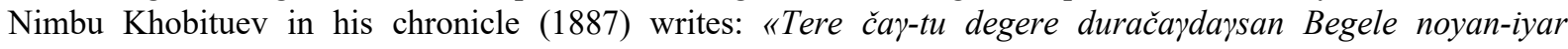

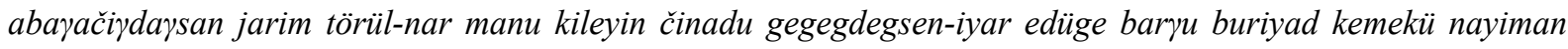

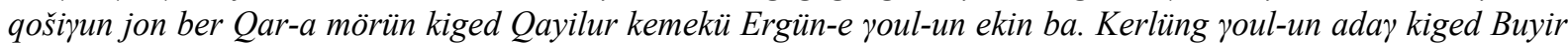

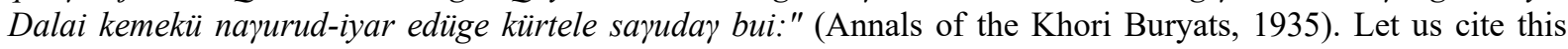
passage in our translation: "At that time, some of our relatives, who had been taken away by the above-mentioned Bayle-noyon, remained abroad. At the present time, they are settled under the name "bargu-buryats" in 8 Khoshuns 
in the basin of the Heilongjiang River (the Amur River - L.B.), at the sources of the rivers Hailar, Ergune, at the mouth of the Kerulen River, as well as at the lakes Buir and Dalai (Khulun), they and now are live in those places".

In support of this fact, the Selenga chronicler Dambi-Zhaltsan Lombotserenov writes about this the following: "Arban nigen köbegün törübei. Tere arban köbegüd-eče delgeregsen öndesün edüge qori arban nigen ečige buriyad. Nige jarim anu ros, dumdadu qoyar ulus-un kili tabiqu čay-tu, tere tala öldegčid, baruyuu-a mongyol gideg olan jon dotur nilegsen qori-yin törül oyirakid edüge olan bui." (Chronicles of the Selenga Buryats, 1936). This fragment in our translation: "Eleven sons were born. The descendants of those eleven sons are now the people of the eleven Khori clans. Some of them, during the establishment of the Russian-Chinese border, remained on the other side and joined with the Bargu-Mongols. There are many representatives of the Khori-Buryat among them".

Thus, the annals of the Buryats testify to the ancient historical ties of the Buryats with the Barguts.

In the field of material culture of the Dagurs, Solons, Barguts, Shenekhen Buryats of China, it is noteworthy that they all use kans (heated box) in their daily life. It is known that the kans were penetrated into the territory of Northern China during the times of the Sung Dynasty (960-1279). Shene Barguts call them laakh < (ma.) nakhan 'warm bunks', the Dagurs call them khual 'chest; kan', and the Shenekhen Buryats - laakha or khaluun khanza (literally) 'hot chest'.

In the language of the chronicle of B. Abida, borrowings from the Chinese language are also used, for example:

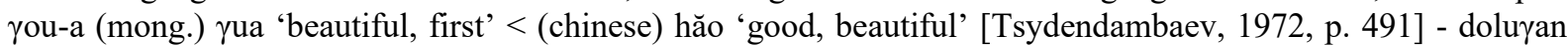

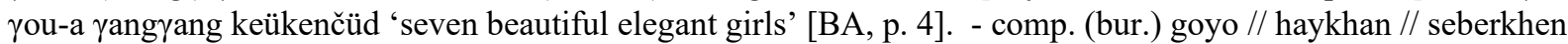

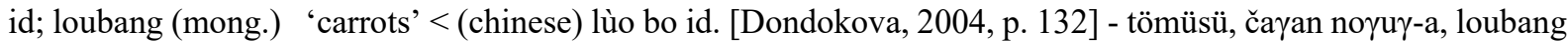
kemke jerge-yi tariqu 'planted potatoes, cabbage, carrots, cucumbers' [Ibid., P. 44] - comp. (bur.) morhoog //

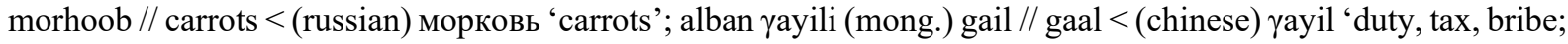

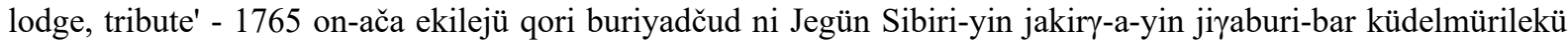

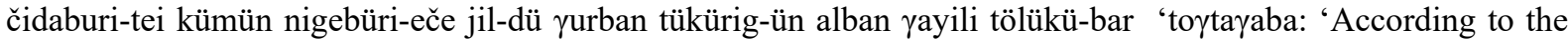
instructions of the administration of Eastern Siberia, it was decided that, starting from 1765, every able-bodied person from the Khori-Buryats will pay 3 rubles a year in tax' [Ibid., P. 34] - comp. (bur.). alba(n) // alban tülberi // alba tatari id.; jing (mong.) jin (g) < (chinese) jīn 'a measure of weight equal to approximately $0.6 \mathrm{~kg}(596,816$ grams)' [Dondokova, 2004, p. 133] - 1790 on-u üy-e-eče ekilejü Ersü (correct - Erkü 'Irkutsk' - LB) qota-daki

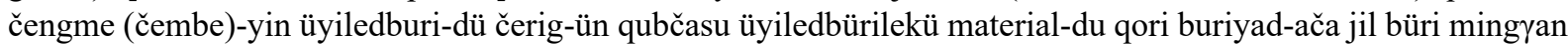
püd (nige püd ni 32 jing) qonin-u noosu-yi ün-e ürdeg-ügei-ber tusiyaqu egürge noүtaju 'Starting from 1790, the Khori-Buryats obliged to deliver a thousand wool to Irkutsk free wool factory for the production of cloth for sewing military uniforms' [BA, p. 34] - in the Buryat language there is no analogy to the term jing. This fragment is borrowed from the ninth chapter of the Khori annals of Vandan Yumsunov [LHB-2, p. 86].

All native speakers speak in their own dialect; in addition, they know literary Mongolian, Chinese, Evenks and Dagur languages. We can note the elements of multilingualism of the Buryats of China. It should be noted that the Shenekhen Buryats, who were lived in isolation for 80 years in a foreign language environment, they not only did not lose their native language, but preserved the language in the best kind, national costume, traditions, customs of the mother ethnos. The field materials testify to the language of the Shenekhen Buryats of China has not undergone much change in comparison with the Aga dialect. Only a few phonetic changes are observed under the influence of the Chinese language, namely, the softening of hissing and whistling sounds: (bur.) beshe - (shen.bur.) $b^{\prime} i s^{\prime} a$ 'other, different'; (bur.) shene - (shen.bur.) s'ine 'new', etc. During the direct contact with the representatives of the Buryat ethnic enclave in the Khulun-Buir Aimak of the Inner Mongolia Autonomous Region PRC (2001, $2002,2003,2004,2005)$ it is noted that the process of loss of the language and the ethnic identity among the Buryats of China received significantly less development than the Buryat ethnos in Russia. The empirical material shows that the one of the most important factors in the consolidation of the ethnic group and the ethnic identity of the Shenekhen Buryats is the language, the possession of the old Mongolian script, which is the traditional letter of the Mongolian peoples. In addition, the sense of national pride and national self-awareness, as well as the factor of the compact settlement of the ethnos in the dominant Mongolian-speaking environment are the factors of their consolidation.

As the ethnographer D. Ts. Boronoeva notes, at present, many researchers see the influence of globalization on the ethnic processes when the ethnic specificity is increasingly losing its significance at the level of material culture and shifts to the mental level, the ethnic groups with the high level of the conservation of the traditional ethnocultural institutions are of the strong interest. To such ethnic groups belong the Buryats of the Inner Mongolia PRC (Shenekhen Buryats) within the framework of the Buryat ethnos. Therefore, it is so important to conduct complex field researches to collect empirical material (Boronoeva, 2006, p7). 
The nature of the migration of the Buryat ethnic group to Barga had primarily the economic and the ethnoprotective character. In our opinion, only the national idea of the returning to the homeland in the future helped to a small Buryat ethnic group to survive and to preserve their ethno-cultural traditions in an incredibly difficult situation in the conditions of a billion foreign-language-speaking (Chinese) environment. All these years, the Shenekhen Buryats lived with a phantom dream of the returning to their homeland, with the dream that someday in the future their descendants would be able to reunite with the mother's ethnic group, so the mixed marriages with the Chinese were not approved. The Shenekhen Buryats do not even burry the bodies of their dead, but burn them in the steppe, because according to their belief, the bones of the dead should not lie in a foreign land, and the smoke must carry their souls to their homeland. There are mixed marriages only with the Khamnigans (Evenks), the Olets.

Some representatives of the Shenekhen Buryats did try to return to their homeland, but life does not stand still. Here they were met by another reality of the modern Russia in conditions of restructuring and market economy, another foreign-language-speaking (Russian) environment. The fact is that the most part of the traditional ethnic and cultural consciousness of the Russian Buryats had undergone a tremendous transformation in the new geopolitical, technological, economic and social realities of the society in conditions of the transparency of the cultural boundaries of the multiethnic environment in which Russian Buryats are situated. The reasons for the changes lie also in the generality of socio-cultural values, in the intensity of communication and in the high degree of cultural borrowings. The degree of changes of the ethnic and linguistic consciousness of the Buryats are so high that scientists expressed concern about the loss of ethnic identity, until acculturation and deethnicization and raised the problem of preserving the cultural identity of the Buryat ethnos.

Many of the Shenekhen Buryats were not able to adapt to the new environment and went back home - to Shenekhen, which had become their homeland.

Nevertheless, it should be noted that the Shenekhen Buryats have the sufficiently high level of adaptive characteristics in extreme conditions. The creative connections with the Buryat diasporas of Russian regions are established, the marriages with the representatives of the ethnic Buryatia are approved, many of them study at the universities of Russia, Japan, America, they teach the old written Mongolian and Chinese languages in schools and at the universities, and some of them have organized successful business in Russia. It is thought that the modern generation of the Shenekhen Buryats of China has a future.

\section{Conclusion}

The work of Bodongut Abyda, created in the best traditions of the Buryat chronicle, is a reliable historical source of the history of the Aga Buryats, who were forced to immigrate to China at the beginning of the 20th century.

Based on the results of the analysis of the language of the narrative about the history of the Shenekhen Buryats written by Bodongut Abida, it was found that the interaction of two contacting language systems when one system dominates will certainly lead to the phenomenon of interference, i.e. the invasion of the norms of one language system within another, or the process of penetration of elements of one language into another. Field materials indicate that the language is more susceptible to influence at the lexical level, because vocabulary is the most mobile and permeable to external influences part of the language. Equally important are the social significance of the dominant language, its demographic power, the status of the state language and historical conditions that determine the direction of influence of one language system on another.

\section{Notes}

Note 1 . The author of these lines was lucky to be familiar with this amazing person. Our last appointment took place on August 15, 2005 in Hailar (China) in the hospitable home of his son Solmon.

Note 2. The data were obtained at the Shenekhen Museum during the expedition to the IMAR PRC (2005).

\section{References}

Annals of the Khori Buryats. (1935). Chronicle of Shirab-Nimbo Khobituev. The text was published by V.A. Kazakevich. / Proceedings of the Institute of Oriental Studies. T. IX. M.-L.: Publishing House of the USSR Academy of Sciences, 2, $125 \mathrm{p}$.

Annals of the Khori Buryats. (1935). Chronicles of Tugultur Toboyev and Vandan Yumsunov. The text was published by N.N. Poppe. / Proceedings of the Institute of Oriental Studies. T. IX. M.-L.: Publishing House of the USSR Academy of Sciences, 1, $172 \mathrm{p}$.

Bodongyud, A. (1983). Buriyad mongyol-un tobči teüke ("The brief history of the Buryat-Mongols"). Öbür mong 
$114 \mathrm{p}$

Boronoeva, D. Ts. (2006). The Buryats of the Inner Mongolia // Ugay zam (The way of the ancestors). № 16. June 2006.

Chronicles of the Selenga Buryats. (1936). Chronicle of ubashi Dambi Dzaltsan Lombotserenov. The text was published by N.N. Poppe. / Proceedings of the Institute of Oriental Studies. T. XII. M. - L.: Publishing House of the USSR Academy of Sciences, $55 \mathrm{p}$.

Dondokova, D. D. (2004). The Chinese borrowing elements in the Buryat language. Ulan-Ude: Publishing House of the Buryat Science Center, P. 120-137.

Tsydendambaev, Ts. B. (1972), The Buryat Historical Chronicles and Genealogies. Ulan-Ude: Buryat Book Publishing House, 662 p.

\section{Copyrights}

Copyright for this article is retained by the author(s), with first publication rights granted to the journal.

This is an open-access article distributed under the terms and conditions of the Creative Commons Attribution license (http://creativecommons.org/licenses/by/4.0/). 